\title{
Moral Molecules: Morality as a Combinatorial System
}

\author{
Oliver Scott Curry ${ }^{1}$ (D) Mark Alfano ${ }^{2} \cdot$ Mark J. Brandt $^{3,4} \cdot$ Christine Pelican $^{5}$
}

Accepted: 14 March 2021/Published online: 11 August 2021

(C) The Author(s) 2021

\begin{abstract}
What is morality? How many moral values are there? And what are they? According to the theory of morality-as-cooperation, morality is a collection of biological and cultural solutions to the problems of cooperation recurrent in human social life. This theory predicts that there will be as many different types of morality as there are different types of cooperation. Previous research, drawing on evolutionary game theory, has identified at least seven different types of cooperation, and used them to explain seven different types of morality: family values, group loyalty, reciprocity, heroism, deference, fairness and property rights. Here we explore the conjecture that these simple moral 'elements' combine to form a much larger number of more complex moral 'molecules', and that as such morality is a combinatorial system. For each combination of two elements, we hypothesise a candidate moral molecule, and successfully locate an example of it in the professional and popular literature. These molecules include: fraternity, blood revenge, family pride, filial piety, gavelkind, primogeniture, friendship, patriotism, tribute, diplomacy, common ownership, honour, confession, turn taking, restitution, modesty, mercy, munificence, arbitration, mendicancy, and queuing. These findings indicate that morality - like many other physical, biological, psychological and cultural systems - is indeed a combinatorial system. Thus morality-as-cooperation provides a principled and powerful theory, that explains why there are many moral values, and successfully predicts what they will be; and it generates a systematic framework that has the potential to explain all moral ideas, possible and actual. Pursuing the many implications of this theory will help to place the study of morality on a more secure scientific footing.
\end{abstract}

What is morality? How many moral values are there? And what are they? According to the theory of morality-as-cooperation, morality is a collection of biological and cultural solutions to the problems of cooperation recurrent in human social life. This theory

OSF Page https://osf.io/qfkz8/

Oliver Scott Curry

oliver.curry@ anthro.ox.ac.uk

Extended author information available on the last page of the article 
predicts that there will be as many different types of morality as there are different types of cooperation. Previous research, drawing on evolutionary game theory, has identified at least seven different types of cooperation, and used them to explain seven different types of morality. Here we show that these simple moral 'elements' combine to form a much larger number of more complex moral 'molecules', and that as such morality is a combinatorial system. Thus we conclude that morality-as-cooperation provides a principled and powerful theory, that explains why there are many moral values, and successfully predicts what they will be; and it generates a systematic framework that has the potential to explain all moral ideas, possible and actual.

The paper proceeds as follows. First we introduce the theory of morality-as-cooperation, and outline seven basic moral elements. Second, we discuss combinatorial systems, and provide some examples of their surprising power. Third, for each combination of two moral elements, we hypothesise candidate moral molecules, and successfully locate examples of them in the professional and popular literature. Fourth, we consider how this combinatorial system extends to include molecules of more than two elements, negatively-valenced (immoral) elements, and different versions of a given molecule; and we speculate on how many moral molecules there might be in total. And fifth, we discuss how the theory of morality as a cooperative combinatorial system might be further tested and developed.

\section{An Overview of Morality-as-Cooperation}

The theory of morality-as-cooperation argues that morality consists of a collection of biological and cultural solutions to the problems of cooperation recurrent in human social life (Curry 2016). ${ }^{1}$

The central idea is that humans are descended from a long line of social primates who have spent 50 million years living in social groups (Shultz et al. 2011), and two million years making a living as intensely collaborative hunter-gatherers (Tooby and DeVore 1987). During this time, humans faced (and continue to face) a range of different problems of cooperation - that is, mutually-beneficial, win-win, nonzerosum social interaction. And they evolved and invented a range of solutions to those problems - ways of unlocking the enormous benefits that cooperation provides. These cooperative solutions come in different shapes and sizes - instincts, intuitions, inventions and institutions. Together these mechanisms provide the motivation for cooperative behaviour; and they provide the criteria by which humans evaluate the behaviour of others. And, according to the theory, it is precisely these solutions to problems of cooperation that constitute human morality (Curry 2005, 2016). 'Morality' is the label that philosophers and others have attached to these cooperative solutions. ${ }^{2}$

\footnotetext{
${ }^{1}$ The following exposition of the theory of morality-as-cooperation closely follows previous expositions, as found in the following papers: (Curry 2016; Curry et al. 2019a; Curry et al. 2019b)

${ }^{2}$ Morality-as-cooperation argues that morality is the name we give to human cooperative traits. Whether or not it is appropriate to give this name to the cooperative traits of other species, and at what point on the phylogenetic 'scale' it becomes appropriate to do so - whether, for example, we reserve the term for cooperation that is facilitated by sophisticated cognitive capacities such as theory of mind, third-party judgement, language, culture, and foresight - are separate questions that we do not tackle here. We note, however, that many ethologists do use the terms 'morality' or 'proto-morality' when discussing cooperative traits in other species. See, for example: (Brosnan 2014).
} 
What's more, the mathematics of cooperation - the theory of nonzerosum games tells us that there is not just one problem of cooperation but many, with many different solutions (Nunn and Lewis 2001; Sachs et al. 2004; Robinson and Goforth 2005; Lehmann and Keller 2006). And so the theory of morality-as-cooperation predicts that there will be not one but many different types of morality - that is, there will be many different cooperative solutions to which the label 'morality' has been attached. In principle, there could be as many different types of morality as there are different types of cooperation. In practice, evolutionary game theory has thus far identified at least seven different types of cooperation: (1) the allocation of resources to kin; (2) coordination to mutual advantage; (3) social exchange; and conflict resolution through contests featuring (4) hawkish displays of dominance and (5) dove-ish displays of submission; (6) division of disputed resources; and (7) recognition of possession. Each of these types of cooperation is immensely valuable. Hence we value it immensely. And these values constitute what we call 'moral' values, namely: (1) family values, (2) group loyalty, (3) reciprocity, (4) heroism, (5) deference, (6) fairness and (7) property rights (Table 1).

\subsection{Family Values}

Natural selection will favour genes that incur a cost to provide a greater benefit to copies of themselves in other individuals (Hamilton 1963; Dawkins 1979). This theory of 'kin selection' predicts that, under some conditions, organisms will possess adaptations for detecting and delivering benefits (or avoiding doing harm) to kin, and thus explains many instances of altruism in many species (Gardner and West 2014), including humans (Kurland and Gaulin 2005; Lieberman et al. 2007). Humans detect kin (Lieberman et al. 2003, 2007), invest in offspring (Smith et al. 1987; Geary 2000), and live in family structures in all societies (Chapais 2014).

Thus kin selection explains why we love and care for our families, why parents feel a duty of care to their offspring, why we feel a special obligation to help our extended families, and why we abhor incest. And morality-as-cooperation - the theory that 'morality' is the label we give to human cooperative traits - explains why these cooperative traits have been considered morally good the world over (Curry et al. 2019b).

Table 1 Seven moral elements

\begin{tabular}{lllll}
\hline Cooperation & Morality & Basic idea & Virtues \\
\hline 1 & Kinship & Family Values & give your family special treatment & $\begin{array}{c}\text { Duty of care, special obligations to } \\
\text { kin }\end{array}$ \\
2 & Mutualism & Group Loyalty & $\begin{array}{c}\text { work together rather than work } \\
\text { alone } \\
\text { Loyalty, unity, solidarity, conformity }\end{array}$ \\
4 & Exchange & Reciprocity & return favours and injuries & $\begin{array}{c}\text { Reciprocity, trustworthiness, } \\
\text { forgiveness }\end{array}$ \\
5 & Dove & Deference & $\begin{array}{l}\text { submit to your superiors } \\
\text { display your power }\end{array}$ & $\begin{array}{l}\text { Respect, humility, awe, reverence } \\
\text { divide disputed resources }\end{array}$ \\
7 & Possession & Property Rights & respect first possession & $\begin{array}{l}\text { Fairness, impartiality, equality } \\
\text { Respect for property, property rights }\end{array}$
\end{tabular}




\subsection{Group Loyalty}

Game theory models situations in which individuals are uncertain about how to behave in order to bring about a mutual benefit as coordination problems (Lewis 1969); and in animal behaviour they are called 'mutualisms'. Organisms use numerous strategies including focal points, traditions, leadership, signalling, badges of membership, and 'theory of mind' - to solve these coordination problems (Alvard 2001; McElreath et al. 2003; Boos et al. 2011; Curry and Jones Chesters 2012), and form stable coalitions and alliances (Harcourt and de Waal 1992; Balliet et al. 2014; Bissonnette et al. 2015).

Thus mutualism explains why we coordinate our activities to pursue projects of mutual interest, why we form groups, clubs and coalitions (there is strength and safety in numbers), why we value these groups, their members, and our membership of them, why we adopt local norms and conventions, why we feel a special obligation to come to the aid of group members, and why we value loyalty, unity and solidarity; and morality-as-cooperation explains why these cooperative traits have been considered morally good the world over (Curry et al. 2019b).

\subsection{Reciprocity}

Social dilemmas - also referred to as prisoners dilemmas, public goods games, tragedies of the commons - arise when cooperation is jeopardised by 'free riders', individuals who take the benefit of cooperation without paying the cost (Ostrom and Walker 2002). This problem can be solved by strategies that make continued cooperation contingent on the continued cooperation of the other parties, such as tit-for-tat (Trivers 1971; Axelrod 1984). Evidence for such contingent cooperation - sometimes referred to as 'reciprocal altruism', or simply 'reciprocity' - has been found in numerous animal species (Carter 2014), including humans (Cosmides and Tooby 2005; Henrich et al. 2005; Jaeggi and Gurven 2013).

Thus social exchange explains why we seek opportunities for mutually-beneficial trade, and why we feel we ought to trust others, return favours (positive reciprocity), keep promises, pay debts, fulfil contracts, be grateful for favours received, feel guilty for favours not returned, avenge injuries (negative reciprocity), punish cheats, apologise for causing injuries, and forgive those who apologise; and morality-as-cooperation explains why these cooperative traits have been considered morally good the world over (Curry et al. 2019b).

\subsection{Heroism}

Organisms often come into conflict over resources such as food, territory, and mates (Huntingford and Turner 1987). These situations provide organisms with opportunities to cooperate to minimise the mutual costs of conflict, in terms of time energy and injury (Maynard Smith and Price 1973). There are three ways of achieving this: contests (involving the display of hawkish and dove-ish traits), division, and recognition of prior possession.

Conflicts can be resolved by means of 'ritual contests', in which individuals display reliable indicators of their 'fighting ability', and the weaker party defers to the stronger (Maynard Smith and Price 1973; Gintis et al. 2001). These contests are widespread in nature (Riechert 1998; Hardy and Briffa 2013), and form the basis of dominance 
hierarchies in which resources are allocated by 'rank' (Preuschoft and van Schaik 2000). Humans have a similar repertoire of status-related behaviours (Mazur 2005; Sell et al. 2009; Fiddick et al. 2013), and social hierarchies (Boone 1992; Rubin 2000). Thus conflict resolution explains why we minimise the mutual costs of disputes by engaging in ritual contests: why we proudly display cues of power and high status ('excellences', including bravery and generosity)...

\subsection{Deference}

....and why, when bested, we express humility, and respect, defer and submit to our superiors. And morality-as-cooperation explains why these hawkish and dove-ish cooperative traits have been considered morally good the world over (Curry 2007; Curry et al. 2019b).

\subsection{Fairness}

Conflicts over divisible resources - 'bargaining problem' (Nash 1950) - can be solved by dividing the resource in proportion to the relative power of the parties (Skyrms 1996). Equally powerful individuals will settle for equal shares (Maynard Smith 1982). Experiments showing non-human primates' adverse reactions to unequal treatment suggest that a 'sense of fairness' is phylogenetically-ancient (Brosnan 2013; Brosnan and de Waal 2014). Humans resolve such disputes by means of heuristics such as "I cut, you choose", "meet in the middle", "split the difference" (Brams and Taylor 1996). Behaviourally, 'equal shares' is a spontaneous and cross-culturally prevalent decision rule in economic games (Henrich et al. 2005) and other situations (Messick 1993).

Thus conflict resolution also explains why we resolve disputes over divisible resources by dividing or sharing them, and hence why we feel an obligation to negotiate, seek a comprise, and be fair; and morality-as-cooperation explains why these cooperative traits have been considered morally good the world over (Curry et al. 2019b).

\subsection{Property Rights}

Finally, conflicts over resources can be resolved by recognition of prior possession (Maynard Smith 1982; Gintis 2007; Hare et al. 2016). Such proto-property rights are widespread in nature (Strassmann and Queller 2014; Sherratt and Mesterton-Gibbons 2015). Humans recognise prior possession in vignette studies (Friedman and Neary 2008; DeScioli and Karpoff 2015), experimental games (Kahneman and Tversky 1979), the law (Rose 1985), and international relations (Johnson and Toft 2014).

Thus conflict resolution also explains why we resolve disputes by recognising prior possession, hence why we feel we ought to respect others' property and territory, and refrain from theft; and morality-as-cooperation explains why these cooperative traits have been considered morally good the world over (Curry et al. 2019b).

In summary, the theory of morality-as-cooperation argues that morality is a collection of cooperative solutions. There are many types of cooperation, so the theory leads us to expect many types of morality; and it tells us what those types will be. They include: family values, group loyalty, reciprocity, bravery, respect, fairness, and 
property rights. ${ }^{3}$ These types of morality are functionally distinct, in that they represent different solutions to different problems: the injunction to 'help your family' is not the same as - and may sometimes conflict with - the injunction to 'recognise prior possession'. They are evolutionarily distinct, in that different types can evolve, and have evolved, independently in different species. For example, many animals respect territory, but few reciprocate. And they are psychologically distinct in humans, in that the degree to which we endorse each of these types of morality can vary independently (Curry et al. 2019a). ${ }^{4}$ In the next section we will see how each of these distinct types of morality can be, and are, combined with each of the others to create a large number of more complex types of morality.

\section{Expanding the Moral Imagination}

A combinatorial system is one in which a small number of simple 'elements' combine to form a very large number of complex 'molecules'. Examples of such systems include: matter, DNA, language, and music. It has been estimated that, in chemistry, the 118 elements of The Periodic Table can be combined to form approximately 13,892,436 molecules (Fink et al. 2005). DNA's four-letter base code can be combined in 64 different codons, which generate 20 amino acids, which in turn are combined to create 30,057 proteins in humans (Kim et al. 2014). The 26 letters of the alphabet combine to form over 600,000 English words (www.oed.com). And in music, six notes can be combined (in various permutations) to form approximately 30 trillion tunes (Niiler 2015). Combinatorial systems provide principled, systematic, comprehensive frameworks that contain all possible (and hence all actual) 'molecules'. Those six musical notes can be used to generate all possible tunes, and all actual tunes can be found somewhere within the system.

Any set of discrete items can, in principle, be combined in this way. This includes the discrete types of morality identified by the theory of morality-as-cooperation. But are these types of morality combined in practice? Faced with combined cooperative problems, do people evolve and invent combined cooperative solutions? And are these too considered moral? Is morality a combinatorial system? If so, then even a relatively small number of simple moral 'elements' could suffice to explain a relatively large number of complex moral 'molecules'. Indeed, with the right elements, such a system would contain all possible (and hence all actual) morals.

As an initial attempt to determine whether morality is in practice a combinatorial system, for each combination of two of the moral 'elements' identified by morality-ascooperation, we hypothesised a candidate moral 'molecule'. 5 e then tried to find

\footnotetext{
${ }^{3}$ The theory also says that, because there are many types of uncooperative behaviour, there are many types of immorality, including: neglecting kin, betraying one's group, free-riding, cowardice, disrespect, unfairness and theft.

${ }^{4}$ Whether these different types of morality are phenotypically distinct - that is, whether they are underpinned by different genetic and neuroanatomical mechanisms ('modules'), as opposed to one more general purpose mechanism - remains an open empirical question (Zakharin et al. in prep; Wilkinson et al. in prep).

${ }^{5}$ There are $n ! / k !(n-k) !$ unique combinations of $k$ elements from a set of $n$ (https://en.wikipedia.org/wiki/ Combination). So there are 21 combinations of 2 elements from a set of seven: $\overline{(7 ! / 2 !(7-2) !=5040 / 2(120)=}$ $\overline{5040 / 240=2} 1$.
} 
examples of these molecules - concepts defined in a way that matched our theoretical expectations, and that had a positive moral valence - in the popular and philosophical literature. We succeeded in every case (Table 2).

\subsection{Fraternity}

The idea that 'you ought to help your group' and the idea that 'you ought to help your family' combine to form the idea that 'you ought to help your group by treating them like family', which is the basis of 'fraternity' - a kind of 'fictive kinship' which involves "the extension of kinship obligations and relationships to individuals specifically not otherwise included in the kinship universe" (Wagner 1995). As Robespierre, who put the fraternity into "Liberté, égalité, fraternité", said: "The men of all countries are brothers and the different peoples should help one another" (Gauthier 1988, p. 33). For further discussion of fraternity - and related concepts such as blood brotherhood, brotherly love, Greek 'adelphopoiesis', Slavic 'pobratimstvo', and Arabic 'milk kinship' - see: (Jones 2000; Qirko 2012; Abou-Abdallah et al. 2016; Leyton 2018).

\subsection{Blood Revenge}

The idea that 'you ought to help your family' and the idea that 'you ought to avenge injuries' combine to form the idea that 'you ought to avenge injuries against your family', which is the basis of 'blood revenge' - "the desire to kill an offender or his... relatives in retaliation for a grave offense committed against oneself or one's relatives" (Souleimanov and Aliyev 2015, p. 159). Kin group vengeance is considered a moral imperative in 38 (and legitimate in 90) of 168 societies for which there are data (Ericksen and Horton 1992). For further discussion of blood revenge - and related concepts such as vendetta, blood money, wergild, Japanese 'kataki-uchi', and Albanian 'gjakmarrja' - see: (Mills 1976; Boehm 1984; Chagnon 1988; Elster 1990).

\subsection{Family Pride}

The idea that 'you ought to be proud of your power and achievements' and the idea that 'you ought to help your family' combine to form the idea that 'you ought to be proud of helping your family', which is the basis of 'family pride' - an "emotion associated with the fulfillment of family obligations and expectations" (Stein et al. 2019, p. 189).

Table 2 Twenty-one moral molecules

\begin{tabular}{|c|c|c|c|c|c|c|}
\hline & Mutualism & Exchange & Hawk & Dove & Division & Possession \\
\hline Kinship & Fraternity & Blood Revenge & Family Pride & Filial Piety & Gavelkind & Primo-geniture \\
\hline Mutualism & & Friendship & Patriotism & Tribute & Diplomacy & Common ownership \\
\hline Exchange & & & Honour & Confession & Turn-taking & Restitution \\
\hline Hawk & & & & Modesty & Mercy & Munificence \\
\hline Dove & & & & & Arbitration & Mendicance \\
\hline Division & & & & & & Queuing \\
\hline
\end{tabular}


Family pride is a facet of 'familism', which has been described as "pride and closeness in the family, which results in family obligations and loyalty coming before individual needs" (Schaefer 2015, p. 188). In a psychological measure of family pride, the Familism Pride Scale, the highest loading item is "I feel fulfilled when I achieve something that will make my family proud" (Stein et al. 2019, p. 193). For further discussion of family pride - such as the related Jewish notion of 'shepping nachas' (Aaronovitch 2017) - see: (Williams and Davies 2017).

\subsection{Filial Piety}

The idea that 'you ought to respect your superiors' and the idea that 'you have special obligations to your family' combine to form the idea that 'you ought to be especially respectful to senior members of your family, such as your parents', which is the basis of 'filial piety" - "[f]aithfulness to the duties naturally owed to one's relatives, superiors, etc.; affectionate loyalty and respect, esp. to parents" (OED 2020h). As Jordan puts it: "The most salient feature of filial piety is the subordination of the will and welfare of each individual to the will and welfare of his or her real classificatory parents"; "quintessentially...the subordination of a son to his father" (Jordan 1998, p. 268; p. 269). For further discussion of filial piety, see: (Nichols 2013; Lum et al. 2016).

\subsection{Gavelkind}

The idea that 'you ought to help your family' and the idea that 'you ought to divide disputed resources' combine to form the idea that 'you ought to help your family by dividing disputed resources equally between them', which is the basis of 'gavelkind' traditionally, "the custom of dividing a deceased man's property equally among his sons" (OED 2020e). Under this system "Every son is as great a gentleman as the eldest son is" (Loyd 1919, p. 165). For the classic discussion of gavelkind, see: (Somner 1660).

\subsection{Primogeniture}

The idea that 'you ought to help your family' and the idea that 'you ought to respect first possession' combine to form the idea that 'you ought to help your family by allocating resources to them on a first-come-first-served basis', which is the basis of 'primogeniture' - "The right of the firstborn child of a family, esp. a son, to succeed or inherit property" (OED 2020i). For further discussion, see: (Hrdy and Judge 1993).

\subsection{Friendship}

The idea that 'you ought to help people who share your interests' and the idea that 'you ought to reciprocate' combine to form the idea that 'you ought to help, and reciprocate favours with, those who share your interests', which is the basis of 'friendship'. Cicero defined friendship as "a complete identity of feeling about all things in heaven and earth: an identity which is strengthened by mutual goodwill and affection". Friendship was "the noblest and most delightful of all the gifts the gods have given mankind" (Cicero 1971, p. 187; p. 201). For further discussion of friendship, see: (Tooby and Cosmides 1996; Mitias 2012; Seyfarth and Cheney 2012; Farmer and Kali 2018). 


\subsection{Patriotism}

The idea that 'you ought to be proud of your power and achievements' and the idea that 'you ought to be loyal to your group' combine to form the idea that 'you ought to be proud of the power and achievements of your group', which is the basis of 'patriotism' - "devotion to a particular place and a particular way of life, which one believes to be the best in the world" (Orwell 1945). As Kosterman puts it: "Patriotism taps the affective component of one's feelings towards one's country...It assesses the degree of love for and pride in one's nation" (Kosterman and Feshbach 1989, p. 271). For further discussion of patriotism, see: (MacIntyre 1984; Keller 2007).

\subsection{Tribute}

The idea that 'you ought to help your group' and the idea that 'you ought to defer to superiors' combine to form the idea that 'you ought to help your group by deferring to superior groups', which is the basis of 'tribute' - "Something paid... by a subordinate to a superior", especially a "tax or impost paid by one prince or state to another in acknowledgement of submission" (OED 20201). As Zhang puts it: "the tributary system exists, first and foremost, as a discourse, articulating the ideas of a cosmic-social order... and of an all-inclusive moral and political order presided over by the Chinese emperor as the embodiment of benevolence and virtue" (Zhang and Buzan 2012, p. 23).

\subsection{Diplomacy}

The idea that 'you ought to help your group' and the idea that 'you ought to divide disputed resources' combine to form the idea that 'you ought to divide disputed resources between groups', which is the basis of 'diplomacy' - the "management of international relations by negotiation" (OED 2020d). As Harold Macmillan put it (paraphrasing Churchill): "Jaw-jaw is better than war-war" (Gilbert 2015, p. 1004).

\subsection{Common Ownership}

The idea that 'you ought to help your group' and the idea that 'you ought to respect property rights' combine to form the idea that 'you ought to further the interests of your group by holding property in common', which is the basis of 'common ownership' - the "[o]wnership...by all members of a group for the mutual benefit of all" (Oxford University Press 2019a). As Saint Ambrose put it (expressing a view common to early Christians): "God ordained everything to be produced to provide food for everyone in common; his plan was that the earth would be, as it were, the common possession of us all" (Ambrose and Davidson 2001, p. 195). Or as Rousseau famously put it: "the fruits of the earth belong equally to us all and the earth itself to nobody!" (Rousseau et al. 2002, p. 113). Common ownership of property is the basis of the political philosophies of socialism (OED 2020k), and communism (Cohen 1986; OED 2020b). 


\subsection{Honour}

The idea that 'you ought to proudly display your power' and the idea that 'you ought to avenge injuries' combine to form the idea that 'you ought to display your power by avenging injuries', which is the basis of 'honour'- to engage "in retaliatory violence... to avoid a significant loss of standing" (Thrasher and Handfield 2018, p. 373). As Saucier puts it, honour is "the belief that male aggression is sometimes appropriate, justifiable, and even necessary as a response to provocation, especially when that provocation insults or threatens a man's manhood" (Saucier et al. 2016, p. 8). For further discussion of honour, see: (Pitt-Rivers 1968; Guerra et al. 2013; Kuschel et al. 2015). ${ }^{6}$

\subsection{Confession}

The idea that 'you ought to feel guilty (and be punished) for failing to reciprocate' and the idea that 'you ought to defer to superiors' combine to form the idea that 'you ought to admit your guilt to (and accept punishment from) your superiors', which is the basis of 'confession' - the "disclosing of something the knowledge of which by others is considered humiliating or prejudicial to the person confessing; a making known or acknowledging of one's fault, wrong, crime, weakness, etc." (OED 2020c). As St Bernard puts it: "God removes the sin of the one who makes humble confession, and thereby the devil loses the sovereignty he had gained over the human heart" (Bernard 1971, p. 34).

\subsection{Turn-Taking}

The idea that 'you ought to divide disputed resources' and the idea that 'you ought to reciprocate' combine to form the idea that 'you ought to divide disputed resources by reciprocating', which is the basis of 'turn taking' - "[a]n opportunity or obligation to do something that comes successively to each of a number of people" (Oxford University Press 2019b). As Lau puts it: "turn taking... allows players to engage in intertemporal sharing of the gain from cooperation" and "reduces the distributional conflict and induces each player to behave less aggressively" (Lau and Mui 2008, p. 153; p. 157). For a model of the evolution of turn-taking, see: (Browning and Colman 2004).

\subsection{Restitution}

The idea that 'you ought to return benefits received (and make amends for injuries imposed)' and the idea that 'you ought to respect first possession' combine to form the idea that 'you ought to return things to their original owners', which is the basis of 'restitution' - the "action of restoring or giving back something to its proper owner" (OED 2020j).

\footnotetext{
${ }^{6}$ Here the focus is on male honour. We are developing a parallel account of female honour (Curry and Sznycer in prep). 


\subsection{Modesty}

The idea that 'you ought to be humble' and the idea that 'you ought to be proud of your achievements' combine to form the idea that 'you ought to be humble about your achievements', which is the basis of 'modesty' - "reserve or reticence arising from an unexaggerated estimate of one's qualities and abilities" (OED 2020g). Note that modesty implies that you have something to be modest about, whereas humility does not (Schueler 1997). Evolutionary models of modesty have shown, paradoxically, that concealing a traits can result in it being valued more highly, if and when it is discovered (Hoffman et al. 2018).

\subsection{Mercy}

The idea that 'you ought to display your power' and the idea that 'you ought to be fair' combine to form the idea that 'you ought to display your power by being fair', which is the basis of 'mercy" - "[c]lemency...shown to a person who is in a position of powerlessness or subjection" (OED 2020f). As Locke put it, mercy is a prerogative of the sovereign: "the power to act according to discretion, for the public good, without the prescription of the Law, and sometimes even against it." (Locke 2011, p. 755). For further discussion of mercy, see: (Garvey 2007).

\subsection{Munificence}

The idea that 'you ought to display your power' and the idea that 'you ought to respect property' combine to form the idea that 'you ought to display your power by donating property', which is the basis of 'munificence' - "great liberality or generosity... a scale of giving appropriate to lords or princes" (Merriam-Webster n.d.). As Carnegie put it: "there is no mode of disposing of surplus wealth creditable to thoughtful and earnest men...save by using it...for the general good....'The man who dies thus rich dies disgraced."' (Carnegie and Kirkland 1962, pp. 28-29). Or, as Zuiderhoek put it when describing euergetism in the Ancient world: "the morally excellent rich man was someone who used (part of) his wealth for the benefit of the whole community. Such men might justifiably claim, and were accorded, social and political influence" (Zuiderhoek 2009, p. 151).

\subsection{Arbitration}

The idea that 'you ought to divide disputed resources (fairly)' and the idea that 'you ought to submit to superiors' combine to form the idea that 'you ought to submit disputes to impartial authorities', which is the basis of 'arbitration' - "The settlement of a dispute...by one to whom the conflicting parties agree to refer their claims in order to obtain an equitable decision" (OED 2020a). As Erasmus put it: "If a disagreement arises between princes, why not go to arbiters...by whose judgment the matter could better be settled than by such slaughter, despoliation, and calamity to the world" (Erasmus and Born 1968, p. 253). And as Cobden put it: "[A]rbitration is more rational, just, and humane than the resort to the sword." (Cobden 1870, p. 394). For mathematical models of arbitration, see: (Jansen and 
Tijs 1981; Boyd and Mathew 2021). For a discussion of 'Solomonic Judgment' in international law, see: (Grossman 2018).

\subsection{Mendicance}

The idea that 'you ought to be humble' and the idea that 'you ought to respect property' combine to form the idea that 'you ought to express humility by disavowing property', which is the basis of 'mendicance' - the (religious) practice of taking a vow of poverty, and begging for food. As St Francis of Assisi put it: "sublime poverty... has made you heirs and kings of the kingdom of heaven: poor in goods, but exalted in virtue" (Francis 1906, p. 69). For discussion of the vows of poverty taken by mendicant orders of Christian monks, see: (Vermeersch 1911).

\subsection{Queuing}

The idea that 'you ought to divide disputed resources' and the idea that 'you ought to respect first possession' combine to form the idea that 'you ought to divide disputed resources by allocating them on a first-come-first served basis', which is the basis of 'queuing'. As Gray puts it: "the underlying norm of queuing behavior draws upon one of the most primitive canons of property jurisprudence- the idea that "first in time is first in right"". Queue-jumping "connotes contempt for the entire normative order of the queue", and elicits a form of "moral outrage" (Gray 2010 , p. 173; p. 185; p. 185). For an experimental demonstration of moral outrage at queue-jumpers, see: (Milgram et al. 1986).

\section{How Many More Morals?}

We have shown that seven simple moral 'elements' (family values, group loyalty, reciprocity, heroism, deference, fairness and property rights) combine to form 21 moral 'molecules' (fraternity, blood revenge, family pride, filial piety, gavelkind, primogeniture, friendship, patriotism, tribute, diplomacy, common ownership, honour, confession, turn taking, restitution, modesty, mercy, munificence, arbitration, mendicancy, and queuing). These findings indicate that morality - like many other physical, biological, psychological and cultural systems - is indeed a combinatorial system, composed of elements that include the seven types of cooperation identified by the theory of morality-as-cooperation.

How many more moral molecules might there be, in addition to the seven elements and 21 molecules identified thus far?

First, there may also be up to 35 'third-order' molecules (combinations of three elements) - for example, a more complicated version of filial piety that combines not only children's deference to their parents, but also the expectation that children should be grateful for, and reciprocate, the parental care they received by taking care of their parents in old age. There may also be up to 35 fourth-order molecules - for example, a more complicated version of honour, that combines not only heroic retaliation for individual injuries, but also heroic retaliation for 
injuries to one's family and group. And so on: 21 fifth-order molecules; 7 sixthorder molecules; 1 seventh-order molecule (the summum bonum); 127 in total. ${ }^{7}$

Second, each of the 'positive' moral elements outlined above has a 'negative' immoral counterpart (neglect, betrayal, cheating, cowardice, disrespect, unfairness, theft). These too can be combined to form 127 immoral molecules - for example, stealing from a family member, or breaking a promise to a chief. And these negative elements can interact with the positive elements to form molecules of mixed valence for example, group loyalty among subordinates plus disrespect for a superior officer equals mutiny. This creates 2186 possible combinations in total. ${ }^{8}$

Third, there may be more than one 'molecule' for each combination of 'elements'. So far we have been assuming that there are equal numbers of elements in each molecule; but the numbers could be unequal. For example, if friendship is one part mutualism and one part reciprocity (MR), perhaps collegiality is one part mutualism and two parts reciprocity $\left(\mathrm{MR}_{2}\right)$, and comradeship is two parts mutualism and one part reciprocity $\left(\mathrm{M}_{2} \mathrm{R}\right)$. If we distinguish molecules according to the relative numbers of constituent (positive and negative) elements, then there are 1,063,622 possible permutations (without ties), and 8,560,946 possible permutations with ties. If we distinguish molecules according to the absolute number of constituent elements, then the possibilities are infinite. It's easy to see how such a system, composed of the right elements, would contain all morals, possible and actual.

\section{The Implications of Morality as a Cooperative Combinatorial System}

Morality-as-cooperation is the first and only theory to make genuine predictions about what moral phenomena there might be in the world. Starting from first principles that are rooted in evolutionary game theory, morality-as-cooperation predicts that there will be many different types of morality, and it predicts that those types will include family values, group loyalty, reciprocity, heroism, deference, fairness and property rights. Having identified these moral 'elements', the theory uses the logic of combinations to generate a huge number of predictions about possible moral 'molecules'. The theory itself doesn't predict which of these many possibilities will be actualities; but the evidence presented above indicates that there are at least 21 molecules, and probably many more. The result is a systematic and potentially comprehensive theoretical framework that can be used: to analyse, organise and explain moral phenomena identified by previous theories and taxonomies; to guide the search for morals not yet discovered; and even to motivate the invention of morals not yet imagined.

\footnotetext{
7 There are $2^{n}-1$ unique combinations of $n$ elements. So there are 127 unique combinations of 7 elements. This figure can be expressed as a $n$-digit number in base two (binary), with each digit representing the presence or absence of the corresponding type of morality: $127_{10}=1111111_{2}$. Incidentally, the binary number provides a system of notation for all 127 morals. For example, $0000001_{2}=1_{10}=$ family; $0000011_{2}=3_{10}=$ family + group $=$ fraternity; $1000001_{2}=65_{10}=$ family + possession $=$ primo-geniture , and so on .

${ }^{8}$ As above, we can represent situations in which moral and immoral elements interact by means of a sevendigit number in base three (ternary), where $0=$ absent, $1=$ positive, and $2=$ negative. As such, there are in total $2222222_{3}=2186_{10}$ possible combinations of moral and immoral elements. Again, this provides a system of notation for all 2186 morals. For example, honour (+heroism, +reciprocity) amongst thieves (-possession) would be represented as $2001100_{3}=1494_{10}$.
} 
With prediction comes testability and falsifiability and the opportunity for the theory to grow and develop in a principled way. For example, the game-theoretic discovery of a new type of cooperation might introduce a new moral element, and new moral molecules. This new eight-element version of the theory would explain everything that the previous seven-element version explained, but also predict and explain new phenomena that the seven-element theory could not explain. (In the same way, the current seven-element version of the theory can explain or reinterpret everything that previous more ad hoc taxonomies - based on three (Rozin et al. 1999), four (Rai and Fiske 2011), and five moral types (Graham et al. 2011) - have identified, and also predict and explain new phenomena, such as all the 21 second-order moral molecules, that these previous accounts cannot explain.) Conversely, the discovery of a moral molecule that could not be analysed into the current seven elements would motivate the search for one or more new elements. ${ }^{9}$

Of course, conceptual analysis is not an exact science; it does not provide a precise method for determining whether a given concept is an example of this or that molecule. And not everyone will be persuaded by all the examples of molecules that we have given above. However, we may hope that, now equipped with the guidelines provided by the theory of morality-as-cooperation, it will be easier to employ more robust empirical methods, such as expert surveys, text mining, and psychological experiments, to help resolve disagreement, and thus make further progress faster.

Morality-as-cooperation raises a number of other empirical questions - new ways of thinking about perennial and unresolved issues in moral thought. First, is morality innate or acquired? Perhaps the answer is 'both'. Perhaps elements are innate, but molecules are acquired. (Or perhaps some molecular problems are so ancient that they have selected for innate molecular solutions.) Second, is morality universal or culturally relative? Again, perhaps the answer is 'both'. Perhaps elements are universal, but molecules are relative (the result of different people combining different elements in different times and places). Third, what is the relationship between elements and molecules? Does endorsement of an element predict endorsement of the molecules that contain it? If elements are innate and universal, and molecules are acquired and relative, is the endorsement of moral elements more stable across cultures than the endorsement of molecules? And fourth, what explains why some molecules exist and others don't? Are some molecules more psychologically stable than others, and if so why? Do patterns of complex moral solutions reflect patterns of complex moral problems? Further empirical work will be needed to answer these questions.

\section{Morality's Mendeleev Moment}

In chemistry, atomic theory replaced earlier folk theories of matter, and led to the development of the Periodic Table of Elements - a principled and systematic framework that isolated distinct elements (and predicted, and thereby facilitated the discovery of, new ones), and explained how these elements combined to form all molecules,

\footnotetext{
${ }^{9}$ And of course, if that new element turned out to be non-cooperative, then the theory would have to be revised more fundamentally, although much of the cooperative elemental and molecular structure could remain within it.
} 
possible and actual. Here we have argued that game theory has replaced earlier folk theories of morality, and has led to the development of a Periodic Table of Ethics - a principled and systematic framework that isolates distinct moral elements (and predicts, and thereby facilitates the discovery of, new ones), and explains how these elements combine to form all moral molecules, possible and actual. Pursuing the many theoretical and empirical implications of the combinatorial logic of morality-as-cooperation will help to place the study of morality on a more secure scientific footing.

Acknowledgments Thanks to Helena Cronin for comments on the manuscript, Les Hearn for help with translations, Gabriel Hudson for research assistance, and Tom Sanders for help with the mathematics of permutations.

Funding This work was supported by The Toyota Foundation (Grant No. TYTID: D17-R-0506) and Kindness.org.

Open Access This article is licensed under a Creative Commons Attribution 4.0 International License, which permits use, sharing, adaptation, distribution and reproduction in any medium or format, as long as you give appropriate credit to the original author(s) and the source, provide a link to the Creative Commons licence, and indicate if changes were made. The images or other third party material in this article are included in the article's Creative Commons licence, unless indicated otherwise in a credit line to the material. If material is not included in the article's Creative Commons licence and your intended use is not permitted by statutory regulation or exceeds the permitted use, you will need to obtain permission directly from the copyright holder. To view a copy of this licence, visit http://creativecommons.org/licenses/by/4.0/.

\section{References}

Aaronovitch, David. 2017. Shepping nachas from the joys of Yiddish. The Jewish Chronicle. (November 6).

Abou-Abdallah, Maria, Yoshihisa Kashima, and Charles Harb. 2016. "Brothers" in arms: Does Metaphorizing kinship increase approval of parochial altruism? Journal of Cognition and Culture 16 (1-2): 37-49. https://doi.org/10.1163/15685373-12342167.

Alvard, M. 2001. Mutualistic hunting. In Meat-eating and human evolution, eds. Craig Stanford and Henry Bunn, 261-278. New York: Oxford University Press.

Ambrose, and Ivor J. Davidson. 2001. De officiis. In Oxford scholarship online, 118-267. Oxford: Oxford University Press.

Axelrod, R. 1984. The evolution of cooperation. New York: Basic Books.

Balliet, Daniel, Junhui Wu, and Carsten K.W. De Dreu. 2014. Ingroup favoritism in cooperation: A metaanalysis. Psychological Bulletin 140 (6): 1556-1581. https://doi.org/10.1037/a0037737.

Bernard, Saint. 1971. The works of Bernard of Clairvaux: On the song of songs I. Cistercian Publications.

Bissonnette, Annie, Susan Perry, Louise Barrett, John C. Mitani, Mark Flinn, Sergey Gavrilets, and Frans B.M. de Waal. 2015. Coalitions in theory and reality: A review of pertinent variables and processes. Behaviour 152 (1): 1-56. https://doi.org/10.1163/1568539X-00003241.

Boehm, C. 1984. Blood revenge: The anthropology of feuding in Montenegro and other tribal societies. Lawrence: The University of Kansas.

Boone, J. 1992. Competition, cooperation and the development of social hierarchies. In Ecology, evolution and social Behavior, E.a. Smith and B. Winterhalder, 301-337 Aldine de Gruyter.

Boos, M., P.M. Kappeler Kolbe, and Th. Ellwart. 2011. Coordination in human and primate groups. Springer.

Boyd, Robert, and Sarah Mathew. 2021. Arbitration supports reciprocity when there are frequent perception errors. Nature Human Behaviour. https://doi.org/10.1038/s41562-020-01008-1.

Brams, Steven J., and Alan D. Taylor. 1996. Fair division: From cake-cutting to dispute resolution. Cambridge University Press. 
Brosnan, Sarah F. 2013. Justice- and fairness-related behaviors in nonhuman primates. Proceedings of the National Academy of Sciences 110 (Supplement 2): 10416-10423. https://doi.org/10.1073/pnas. 1301194110.

Brosnan, Sarah F. 2014. Precursors of morality - Evidence for moral behaviors in non-human Primates. In Empirically informed ethics: Morality between facts and norms, eds. Markus Christen, Carel van Schaik, Johannes Fischer, Markus Huppenbauer, and Carmen Tanner, 85-98. Cham: Springer International Publishing.

Brosnan, Sarah F., and Frans B.M. de Waal. 2014. Evolution of responses to (un)fairness. Science (New York, N.Y.) 346 (6207): 1251776-1251776. https://doi.org/10.1126/science. 1251776.

Browning, Lindsay, and Andrew M. Colman. 2004. Evolution of coordinated alternating reciprocity in repeated dyadic games. Journal of Theoretical Biology 229 (4): 549-557. https://doi.org/10.1016/j.jtbi. 2004.04.032.

Carnegie, Andrew, and Edward C. Kirkland. 1962. The gospel of wealth, and other timely essays. John Harvard library. Cambridge: Belknap Press of Harvard University Press.

Carter, Gerald G. 2014. The reciprocity controversy. Animal Behavior and Cognition 1 (3): 368-386.

Chagnon, Napoleon. 1988. Life histories, blood revenge, and warfare in a tribal population. Science 239 (4843): 985. https://doi.org/10.1126/science.239.4843.985.

Chapais, B. 2014. Complex kinship patterns as evolutionary constructions, and the origins of sociocultural universals. Current Anthropology 55 (6): 751-783. https://doi.org/10.1086/678972.

Cicero, M.T. 1971. On the good life. Penguin Classics.

Cobden, R. 1870. Speeches on questions of public policy, eds. J. Bright and J. E. T. Rogers, vol. 2.

Cohen, G.A. 1986. Self-ownership, world ownership, and equality: Part II. Social Philosophy and Policy 3 (2): 77-96. https://doi.org/10.1017/S0265052500000315.

Cosmides, L., and J. Tooby. 2005. Neurocognitive adaptations designed for social exchange. In The handbook of evolutionary psychology, ed. D.M. Buss, 584-627. New York: Wiley.

Curry, Oliver Scott. 2005. Morality as natural history: An adaptationist account of ethics. London: $\mathrm{PhD}$, London School of Economics.

Curry, Oliver Scott. 2007. The conflict-resolution theory of virtue. In Moral psychology, ed. W.P. SinnottArmstrong, 251-261. Cambridge: MIT Press.

Curry, Oliver Scott. 2016. Morality as cooperation: A problem-centred approach. In The evolution of morality, eds. Todd K. Shackelford and Ranald D. Hansen, 27-51. Evolutionary Psychology: Springer International Publishing.

Curry, Oliver Scott, and M. Jones Chesters. 2012. Put yourself in the other fellow's shoes': The role of 'theory of mind' in solving coordination problems. Journal of Cognition and Culture 12: 147-159.

Curry, Oliver Scott, and D Sznycer. in prep. Explaining sexual morality. https://osf.io/g9kr4/.

Curry, Oliver Scott, Matthew Jones Chesters, and Caspar J. Van Lissa. 2019a. Mapping morality with a compass: Testing the theory of 'morality-as-cooperation' with a new questionnaire. Journal of Research in Personality 78: 106-124. https://doi.org/10.1016/j.jrp.2018.10.008.

Curry, Oliver Scott, D.A. Mullins, and H. Whitehouse. 2019b. Is it good to cooperate? Testing the theory of morality-as-cooperation in 60 societies. Current Anthropology 60 (1): 47-69. https://doi.org/10.1086/ 701478 .

Dawkins, R. 1979. Twelve misunderstandings of kin selection. Zeitschrift für Tierpsychologie 51 (2): 184 200. https://doi.org/10.1111/j.1439-0310.1979.tb00682.x.

DeScioli, Peter, and Rachel Karpoff. 2015. People's judgments about classic property law cases. Human Nature 26 (2): 184-209. https://doi.org/10.1007/s12110-015-9230-y.

Elster, Jon. 1990. Norms of revenge. Ethics 100 (4): 862-885. https://doi.org/10.1086/293238.

Erasmus, Desiderius, and Lester Kruger Born. 1968. The education of a Christian prince. ACLS humanities ebook. New York: Norton.

Ericksen, Karen Paige, and Heather Horton. 1992. "blood feuds": Cross-cultural variations in kin group vengeance. Cross-Cultural Research 26 (1-4): 57-85. https://doi.org/10.1177/106939719202600103.

Farmer, A., and R. Kali. 2018. Friendship, not altruism: An economic theory with cross-cultural applications. Review of Social Economy 76 (1): 119-145. https://doi.org/10.1080/00346764.2017.1349331.

Fiddick, Laurence, Denise Dellarosa Cummins, Maria Janicki, Sean Lee, and Nicole Erlich. 2013. A crosscultural study of noblesse oblige in economic decision-making. Human Nature 24 (3): 318-335. https:// doi.org/10.1007/s12110-013-9169-9.

Fink, Tobias, Heinz Bruggesser, and Jean-Louis Reymond. 2005. Virtual exploration of the small-molecule chemical universe below 160 Daltons. Angewandte Chemie International Edition 44 (10): 1504-1508. https://doi.org/10.1002/anie.200462457.

Francis. 1906. The writings of Saint Francis of Assisi. Philadelphia: Dolphin Press. 
Friedman, Ori, and Karen R. Neary. 2008. Determining who owns what: Do children infer ownership from first possession? Cognition 107 (3): 829-849. https://doi.org/10.1016/j.cognition.2007.12.002.

Gardner, A., and S.A. West. 2014. Special issue: Inclusive fitness; 50 years on. Philosophical Transactions of the Royal Society B: Biological Sciences 369.

Garvey, Stephen P. 2007. Questions of mercy. Ohio State Journal of Criminal Law 4 (2): 321-327.

Gauthier, F. 1988. Universal rights and National Interest in the French. In Nationalism in the age of the French revolution, O. Dann and J. Dinwiddy, 27-38 Bloomsbury Academic.

Geary, D.C. 2000. Evolution and proximate expression of human paternal investment. Psychological Bulletin 126: $55-77$.

Gilbert, M. 2015. Winston S. Churchill: Never Despair, 1945-1965 (Vol. 8): Rosetta Books.

Gintis, H. 2007. The evolution of private property. Journal of Economic Behavior \& Organization 64 (1): 116.

Gintis, H., E.A. Smith, and S. Bowles. 2001. Costly signaling and cooperation. Journal of Theoretical Biology 213: 103-119. https://doi.org/10.1006/jtbi.2001.2406.

Graham, J., B.A. Nosek, J. Haidt, R. Iyer, S. Koleva, and P.H. Ditto. 2011. Mapping the moral domain. Journal of Personality and Social Psychology 101 (2): 366-385. https://doi.org/10.1037/A0021847.

Gray, K. 2010. Property in a queue. In Property and community, eds. Gregory S. Alexander and Eduardo M. Peñalver, 165-195. Oxford: Oxford University Press.

Grossman, Nienke. 2018. Solomonic judgments and the legitimacy of the international court of justice. In: Legitimacy and International C, eds. Andreas Follesdal, Geir Ulfstein, Harlan Grant Cohen, and Nienke Grossman, 43-61. Studies on international courts and tribunals. Cambridge: Cambridge University Press.

Guerra, Valeschka Martins, Roger Giner-Sorolla, and Milica Vasiljevic. 2013. The importance of honor concerns across eight countries. Group Processes \& Intergroup Relations 16 (3): 298-318. https://doi. org/10.1177/1368430212463451.

Hamilton, W.D. 1963. The evolution of altruistic behavior. The American Naturalist 97: 354-356.

Harcourt, A., and F.B.M. de Waal. 1992. Coalitions and alliances in humans and other animals. Oxford: Oxford University Press.

Hardy, C.W., and M. Briffa. 2013. Animal contests. Cambridge: Cambridge University Press.

Hare, D., H.K. Reeve, and B. Blossey. Evolutionary routes to stable ownership. Journal of Evolutionary Biology 29 (6): 1178-1188. https://doi.org/10.1111/jeb.12859.

Henrich, J., R. Boyd, S. Bowles, C. Camerer, E. Fehr, H. Gintis, R. McElreath, et al. 2005. 'Economic Man' in cross-cultural perspective: Behavioral experiments in 15 small-scale societies. Behavioral and Brain Sciences 28 (6): 795-855.

Hoffman, Moshe, Christian Hilbe, and Martin A. Nowak. 2018. The signal-burying game can explain why we obscure positive traits and good deeds. Nature Human Behaviour 2 (6): 397-404. https://doi.org/10.1038/ s41562-018-0354-z.

Hrdy, S.B., and D.S. Judge. 1993. Darwin and the puzzle of primogeniture - an essay on biases in parental investment after death. Human Nature-An Interdisciplinary Biosocial Perspective 4 (1): 1-45. https://doi. org/10.1007/bf02734088.

Huntingford, F.A., and A.K. Turner. 1987. Animal Conflict. London: Chapman and Hall.

Jaeggi, Adrian V., and Michael Gurven. 2013. Reciprocity explains food sharing in humans and other primates independent of kin selection and tolerated scrounging: A phylogenetic meta-analysis. Proceedings of the Royal Society of London B: Biological Sciences 280 (1768).

Jansen, M.J.M., and S.H. Tijs. 1981. Arbitration Games. A Survey. Berlin: Springer.

Johnson, Dominic D.P., and Monica Duffy Toft. 2014. Grounds for war: The evolution of territorial conflict. International Security 38 (3): 7-38. https://doi.org/10.1162/ISEC_a_00149.

Jones, D. 2000. Group nepotism and human kinship. Current Anthropology 41 (5): 779-809.

Jordan, D.K. 1998. Filial piety in Taiwanese popular thought. In Confucianism and the family, eds. W.H. Slote and G.A. DeVos, 267-284. Albany: State University of New York Press.

Kahneman, D., and A. Tversky. 1979. Prospect Theory: An analysis of decision under risk. Econometrica: 263-291.

Keller, Simon. 2007. What is patriotism? In The limits of loyalty, ed. Simon Keller, 52-70. Cambridge: Cambridge University Press.

Kim, Min-Sik, Sneha M. Pinto, Derese Getnet, Raja Sekhar Nirujogi, Srikanth S. Manda, Raghothama Chaerkady, and Anil K. Madugundu, et al. 2014. A draft map of the human proteome. Nature 509 (7502): 575-581. https://doi.org/10.1038/nature13302.

Kosterman, Rick, and Seymour Feshbach. 1989. Toward a measure of patriotic and nationalistic attitudes. Political Psychology 10 (2): 257-274. https://doi.org/10.2307/3791647. 
Kurland, J., and S. Gaulin. 2005. Cooperation and conflict among kin. In The handbook of evolutionary psychology, ed. D.M. Buss, 447-482. Hoboken: John Wiley \& Sons.

Kuschel, Rolf, Angikinui F. Takiika, and Kiu Angiki. 2015. Aspects of social stratification and honour on preChristian and modern Mungiki (Bellona). South Pacific Journal of Psychology 11 (1): 54-70. https://doi. org/10.1017/S0257543400000754.

Lau, Sau-Him Paul, and Vai-Lam Mui. 2008. Using turn taking to mitigate coordination and conflict problems in the repeated Battle of the sexes game. Theory and Decision 65 (2): 153-183. https://doi.org/10.1007/ s11238-008-9100-8.

Lehmann, L., and L. Keller. 2006. The evolution of cooperation and altruism - A general framework and a classification of models. Journal of Evolutionary Biology 19 (5): 1365-1376. https://doi.org/10.1111/j. 1420-9101.2006.01119.x.

Lewis, D.K. 1969. Convention: A philosophical study. Cambridge: Harvard University Press.

Leyton, Cristian Alvarado. 2018. Ritual and fictive kinship. In The international encyclopedia of anthropology, H. Callan, 1-3. Wiley.

Lieberman, D., J. Tooby, and L. Cosmides. 2003. Does morality have a biological basis? An empirical test of the factors governing moral sentiments relating to incest. Proceedings of the Royal Society of London Series B-Biological Sciences 270 (1517): 819-826. https://doi.org/10.1098/Rspb.2002.2290.

Lieberman, D., J. Tooby, and L. Cosmides. 2007. The architecture of human kin detection. Nature 445 (7129): 727-731. https://doi.org/10.1038/Nature05510.

Locke, J. 2011. Second treatise of government. In Classics of moral and political Theory, ed. M.L. Morgan, 711-776. Indianapolis: Hackett.

Loyd, William H. 1919. Partition. University of Pennsylvania Law Review and American Law Register 67 (2): 162-190. https://doi.org/10.2307/3314500.

Lum, Terry Y.S., Elsie C.W. Yan, Andy H.Y. Ho, Michelle H.Y. Shum, Gloria H.Y. Wong, Mandy M.Y. Lau, and Junfang Wang. 2016. Measuring filial piety in the 21st century: Development, factor structure, and reliability of the 10-item contemporary filial piety scale. Journal of Applied Gerontology 35 (11): 1235-1247. https://doi.org/10.1177/0733464815570664.

MacIntyre, A. 1984. Is patriotism a virtue? (the Lindley lecture). Lawrence: University of Kansas.

Maynard Smith, J. 1982. Evolution and the Theory of games. Cambridge: Cambridge University Press.

Maynard Smith, J., and G.R. Price. 1973. The logic of animal conflict. Nature 246: 15-18.

Mazur, A. 2005. Biosociology of dominance and deference. Lanham: Rowan \& Littlefield.

McElreath, R., R. Boyd, and P.J. Richerson. 2003. Shared norms and the evolution of ethnic markers. Current Anthropology 44 (1): 122-129.

Merriam-Webster. n.d. Munificent. In Merriam-Webster.com.

Messick, D.M. 1993. Equality as a decision rule. In Psychological perspectives on justice, eds. B. Mellers and J. Baron, 11-31. Cambridge: Cambridge University Press.

Milgram, Stanley, Hilary Liberty, Raymond Toledo, and Joyce Wackenhut. 1986. Response to intrusion into waiting lines. Journal of Personality and Social Psychology 51 (4): 683. https://doi.org/10.1037/00223514.51.4.683.

Mills, D.E. 1976. Kataki-uchi: The practice of blood-revenge in pre-modern Japan. Modern Asian Studies 10 (4): 525-542. https://doi.org/10.1017/S0026749X00014943.

Mitias, Michael H. 2012. Friendship: A central moral value. Value inquiry book series; v. 239. Amsterdam: Rodopi.

Nash, J. 1950. The bargaining problem. Econometrica: 155-162.

Nichols, Ryan. 2013. The origins and effects of filial piety (Xiao 孝): How culture solves an evolutionary problem for parents. Journal of Cognition and Culture 13: 201-230.

Niiler, Eric. 2015. Blurred lines: Is the number of pop tunes finite? Seeker. Accessed 29th May 2020.

Nunn, C.L., and R.J. Lewis. 2001. Cooperation and collective action in animal behaviour. In Economics in nature: Social dilemmas, mate choice and biological markets, 42-66. Cambridge: CUP.

OED. 2020a. arbitration, $n$. In OED Online: Oxford University Press.

OED. 2020b. communism, $n$. In OED Online: Oxford University Press.

OED. 2020c. confession, $n$. In OED Online: Oxford University Press.

OED. 2020d. diplomacy, $n$. In OED Online: Oxford University Press.

OED. 2020e. gavelkind, $n$. In OED Online: Oxford University Press.

OED. 2020f. Mercy, $n$. and int. In OED Online: Oxford University Press.

OED. 2020g. modesty, $n$. In OED Online: Oxford University Press.

OED. 2020h. piety, $n$. In OED Online. https://www.oed.com/view/Entry/143641?rskey=dlWSfL\&result=1:

Oxford University Press.

OED. 2020i. primogeniture, $n$. In OED Online: Oxford University Press. 
OED. 2020j. restitution, $n$. In OED Online: Oxford University Press.

OED. 2020k. socialism, $n$. In OED Online: Oxford University Press.

OED. 20201. tribute, $n$. In OED Online: Oxford University Press.

Orwell, G. 1945. Notes on nationalism. Polemic. Retrieved from https://www.orwellfoundation.com/theorwell-foundation/orwell/essays-and-other-works/notes-on-nationalism/.

Ostrom, Lin, and James Walker. 2002. Trust and reciprocity: Interdisciplinary lessons from experimental research. New York: Russell Sage Foundation.

Oxford University Press. 2019a. Collective ownership. In https://Lexico.com/.

Oxford University Press. 2019b. Turn. In Lexico.com.

Pitt-Rivers, J. 1968. Honor. In International encyclopedia of the social sciences, ed. D. Sills vol. 6, 503-511. New York: Macmillan.

Preuschoft, S., and C.P. van Schaik. 2000. Dominance and communication: Conflict management in various social settings. In Natural conflict resolution, eds. F. Aureli and F.B.M. de Waal, 77-105. Berkeley: University of California Press.

Qirko, H.N. 2012. Fictive kinship and induced altruism. In The Oxford handbook of evolutionary family psychology, eds. T.K. Shackelford and C.A. Salmon. Oxford University Press.

Rai, Tage Shakti, and A.P. Fiske. 2011. Moral psychology is relationship regulation: Moral motives for unity, hierarchy, equality, and proportionality. Psychological Review 118 (1): 57-75. https://doi.org/10.1037/ a0021867.

Riechert, S E. 1998. Game theory and animal contests. In Game theory and animal behavior, eds. Lee Alan Dugatkin, and Hudson Kern Reeve, 64-93. Oxford: Oxford University Press.

Robinson, D.R., and D.J. Goforth. 2005. The topology of $2 x 2$ games: A new periodic table. London: Routledge.

Rose, Carol M. 1985. Possession as the origin of property, 73-88. University of Chicago Law Review.

Rousseau, Jean-Jacques, Susan Dunn, and Gita May. 2002. The social contract [electronic resource]: And, the first and second discourses. In Rethinking the Western tradition. New Haven, Yale University Press.

Rozin, P., Laura Lowery, Sumio Imada, and J. Haidt. 1999. The CAD triad hypothesis: A mapping between three moral emotions (contempt, anger, disgust) and three moral codes (community, autonomy, divinity). Journal of Personality and Social Psychology 76 (4): 574-586. https://doi.org/10.1037/0022-3514.76.4. 574.

Rubin, P.H. 2000. Hierarchy. Human Nature 11 (3): 259-279.

Sachs, J.L., U.G. Mueller, T.P. Wilcox, and J.J. Bull. 2004. The evolution of cooperation. The Quarterly Review of Biology 79 (2): 135-160. https://doi.org/10.1086/383541.

Saucier, Donald A., Amanda J. Stanford, Stuart S. Miller, Amanda L. Martens, Alyssa K. Miller, Tucker L. Jones, Jessica L. McManus, and Mason D. Burns. 2016. Masculine honor beliefs: Measurement and correlates. Personality and Individual Differences 94 (C): 7-15. https://doi.org/10.1016/j.paid.2015.12. 049.

Schaefer, Richard T. 2015. Racial and ethnic groups. Fourteenth. Global ed. Boston: Pearson.

Schueler, G.F. 1997. Why modesty is a virtue. Ethics 107 (3): 467-485. https://doi.org/10.1086/233745.

Sell, A., J. Tooby, and L. Cosmides. 2009. Formidability and the logic of human anger. Proceedings of the National Academy of Sciences of the United States of America 106 (35): 15073-15078. https://doi.org/10. 1073/Pnas.0904312106.

Seyfarth, Robert M., and Dorothy L. Cheney. 2012. The evolutionary origins of friendship. In Annual review of psychology, vol 63, eds. S. T. Fiske, D. L. Schacter, and S. E. Taylor, 153-177. Annual Review of Psychology.

Sherratt, T.N., and M. Mesterton-Gibbons. 2015. The evolution of respect for property. Journal of Evolutionary Biology 28 (6): 1185-1202. https://doi.org/10.1111/jeb.12648.

Shultz, Susanne, Christopher Opie, and Quentin D. Atkinson. 2011. Stepwise evolution of stable sociality in primates. Nature 479 (7372): 219-222 http://www.nature.com/nature/journal/v479/n7372/abs/ nature10601.html\#supplementary-information.

Skyrms, B. 1996. Evolution of the social contract. Cambridge: Cambridge University Press.

Smith, Martin S., Bradley J. Kish, and Charles B. Crawford. 1987. Inheritance of wealth as human kin investment. Ethology and Sociobiology 8 (3): 171-182. https://doi.org/10.1016/0162-3095(87)90042-2.

Somner, William. 1660. A treatise of gavelkind, both name and thing [microform] : Shewing the true etymologie and derivation of the one, the nature, antiquity, and original of the other : With sundry emergent observations, both pleasant and profitable to be known of Kentish-men and others, especially such as are studious, either of the ancient custome, or the common law of this kingdome / by (a wellwiller to both) William Somner. Early English books, 194 (3): 1641-1700. Accessed from https://nla.gov. 
au/nla.cat-vn2358452. London: Printed by R. and W. Leybourn for the authour, and are to be sold by John Crooke ... And Daniel white.

Souleimanov, Emil, and Huseyn Aliyev. 2015. Blood revenge and violent mobilization: Evidence from the Chechen wars. International Security 40 (2): 158-180. https://doi.org/10.1162/ISEC_a_00219.

Stein, Gabriela Livas, Alyson M. Cavanaugh, Laura Castro-Schilo, Yesenia Mejia, and Scott W. Plunkett. 2019. Making my family proud: The unique contribution of familism pride to the psychological adjustment of Latinx emerging adults. Cultural Diversity and Ethnic Minority Psychology 25 (2): 188198. https://doi.org/10.1037/cdp0000223.

Strassmann, Joan E., and David C. Queller. 2014. Privatization and property in biology. Animal Behaviour. https://doi.org/10.1016/j.anbehav.2014.02.011.

Thrasher, John, and Toby Handfield. 2018. Honor and violence. Human Nature. https://doi.org/10.1007/ s12110-018-9324-4.

Tooby, J., and L. Cosmides. 1996. Friendship and the banker's paradox: Other pathways to the evolution of adaptations for altruism. In Evolution of social behaviour patterns in Primates and man, eds. W.G. Runciman, John Maynard Smith, and Robin I.M. Dunbar, 119-143. Oxford: British Academy/Oxford University Press.

Tooby, J., and I. DeVore. 1987. The reconstruction of hominid behavioral evolution through strategic modeling. In The evolution of human behavior: Primate models, ed. W.G. Kinzey, 183-237. Albany: SUNY Press.

Trivers, R.L. 1971. The evolution of reciprocal altruism. Quarterly Review of Biology 46 (1): 35-57. https:// doi.org/10.1086/406755.

Vermeersch, A. 1911. Poverty. In the catholic encyclopedia. New York: Robert Appleton Company.

Wagner, R. A. 1995. Fictive kinship. Marriage and family encyclopedia: relatives \& extended family.

Wilkinson, J., O.S. Curry, B. Mitchell, N. Martin, and T.C. Bates. in prep. Modular morals: mapping the organisation of the moral brain. Retrieved from https://osf.io/h3n9a/.

Williams, L.A., and J. Davies. 2017. Beyond the self: Pride felt in relation to others. In The moral psychology of pride, eds. J. Adam Carter and Emma C. Gordon, 43-68. Rowman \& Littlefield.

Zakharin, M., Curry, O. S., Martin, N. G., Lewis, G. J., and Bates, T. C. in prep. Modular morals: the genetic architecture of morality as cooperation. https://osf.io/kms $9 \mathrm{c} /$.

Zhang, Yongjin, and Barry Buzan. 2012. The tributary system as International Society in Theory and Practice. Chinese Journal of International Politics 5 (1): 3-36. https://doi.org/10.1093/cjip/pos001.

Zuiderhoek, Arjan. 2009. The politics of munificence in the Roman empire: Citizens, elites and benefactors in Asia minor. Greek Culture in the Roman World. Cambridge: Cambridge University Press.

Publisher's Note Springer Nature remains neutral with regard to jurisdictional claims in published maps and institutional affiliations.

\section{Affiliations}

\section{Oliver Scott Curry ${ }^{1} \cdot$ Mark Alfano $^{2} \cdot$ Mark J. Brandt $^{3,4} \cdot$ Christine Pelican $^{5}$}

1 Institute of Cognitive and Evolutionary Anthropology, University of Oxford, 64 Banbury Road, Oxford OX2 6PN, UK

2 Department of Philosophy, Macquarie University, Sydney, Australia

3 Department of Psychology, Michigan State University, East Lansing, MI, USA

4 Department of Social Psychology, Tilburg University, Tilburg, Netherlands

5 Department of Politics and International Relations, University of Oxford, Oxford, UK 